\title{
The Implementation of Bottom Up Planning for Village Development Through Village Development Planning in Tumbang Tariak Village, Kurun District, Gunung Mas District, Central Kalimantan
}

Christira Elyswandi ${ }^{*}$, Samahuddin Muharam, Setia Budhi

Master of Governmental Science, Faculty of Social and Political Science, Lambung Mangkurat University, Banjarmasin, Indonesia

DOI: $10.36348 /$ sijlcj.2021.v04i02.011

| Received: 08.02.2021 | Accepted: 22.02.2021 | Published: 26.02.2021

*Corresponding author: Christira Elyswandi

\section{Abstract}

This study aims to identify and analyze the implementation of bottom-up planning and supporting factors as well as inhibiting factors for the implementation of bottom-up planning village development planning through Musrenbangdes in Tumbang Tariak village, Kurun District, Gunung Mas Regency. The research method used in this research is a qualitative research approach with a descriptive-analytic type. While the data collection techniques used in this study were interviews, observation, and documentation. The data analysis technique used is the model developed by Miles and Hubermen, namely interactive analysis. The informants in this study were 1) village head and village secretary tumbang tariak, 2) head of BPD, 3) sub-district head, 4) head of government, head of PMD, and head of ekobang of kurun subdistrict, and 5) traditional leaders, community leaders, youth leaders and from representatives of women from the village of Tumbang Tariak. The results showed that the implementation of bottom-up planning village development through Musrenbangdes in the preparation and determination of the village medium-term development plan (RPJM Des) and the village government work plan (RKP Des) in the village of Tumbang Tariak, Kurun District has been running effectively as seen from the aspect of productivity. Aspects of efficiency and aspects of satisfaction (output) with the results of village development planning activities.

Keyword: Effectiveness, Bottom Up Planning, Musrembangdes, Participants.

Copyright ( $) 2021$ The Author(s): This is an open-access article distributed under the terms of the Creative Commons Attribution 4.0 International License (CC BY-NC 4.0) which permits unrestricted use, distribution, and reproduction in any medium for non-commercial use provided the original author and source are credited.

\section{INTRODUCTION}

The village and village government in the reform era became interesting objects for discussion and study. Enforcement of Law No. 6 of 2014 concerning villages and village fund policies in the context of implementing village development from the central government which is disbursed directly into village government accounts through the Ministry of Villages, PDT and Transmigration 1 amounting to (one) billion one village becomes a separate magnet that turns village attractiveness into an object of study new issues are not only related to development policies, public services, and social community development but also related to development planning and accountability of village fund financial management. Lutfhi [1] states that the implementation of village fund policies has a real and positive effect on village financial management and the effectiveness of village development programs.

Development planning is an early stage in the development process before it is implemented to adjust the goals to be achieved in development with existing resources and various other alternatives that may be needed (PK2A3 LAN Samarinda [2]). Village development planning can be defined as a development planning process that is intended to make changes towards a better development direction for village communities by utilizing or utilizing various existing resources and must have an orientation that is comprehensive, complete, but still adhering to the principle of priority. Determination of development programs by the community is a form of development planning that is bottom-up planning. This planning encourages the involvement and active participation of all components of society. The government only facilitates and encourages village communities to be able to actively participate in village development. Increasing community participation is a real and measurable form of community empowerment [3].

Creating village development activities that are effective, efficient, and targeted requires good village development planning. Good village development 
Christira Elyswandi et al., Sch Int J Law Crime Justice, Feb, 2021; 4(2): 105-109

planning is development planning that involves the active participation and participation of the village community. Every village development is always carried out by village meetings which are then called village development planning meetings to receive input and suggestions from the community which is used as the initial basis for village development planning using a priority scale system. Musrenbang is a public space that is useful for accommodating community aspirations and public complaints regarding future development, starting from identifying problems, needs, external challenges, existing potentials, and solving problems faced by the community. Musrenbang is held at every level starting from the village, sub-district, sub-district, district/city, province to the national level. Handayaningrat [4] further emphasizes that if the goals or objectives have been achieved as previously planned, the village planning can be said to be effective. The general criteria for measuring organizational effectiveness, in this case, the village government, are productivity, efficiency, flexibility, and satisfaction. The factors that can become obstacles in village development planning include human resources, budget, planning, communication, authority, information, and participation. Based on the description above, it can be concluded that the measures related to the effectiveness of village development planning in this study are related to productivity, efficiency, and satisfaction with the results of the compiled plans.

Tumbang Tariak Village is one of the villages in the Kurun Subdistrict, Gunung Mas Regency; the original inhabitants are the Dayak Ngaju tribe. The village government collapsed under the leadership of the village head Rodi asser for the 2016-2021 term of office, there was significant progress in various fields, both village government, development, empowerment and village community several advantages in planning and village development. In connection with this explanation, the authors are very interested in examining more deeply the phenomenon of the implementation of bottom up planning village development as well as supporting and inhibiting factors in Tumbang Tariak village, Kurun District, Gunung Mas Regency, South Kalimantan Province. The research title raised by the researcher was the implementation of bottom-up planning village development through village development planning deliberations in the village of Tumbang Tariak, Kurun District, Gunung Mas Regency, Central Kalimantan.

\section{RESEARCH METHODS}

This study used a qualitative approach to find out exactly the description of the implementation of bottom-up planning village development planning through musrenbangdes in determining and validating village development planning in villages within the subdistrict of Gunung Mas district. The pattern of thinking developed in this approach is inductive thinking, which is thought that is built from observing a series of phenomena which is then connected with a number of theoretical conceptions so that they become a unit of thinking in the solution of the defined problem. This type of research is descriptive-analytic, that is, the type of research that draws the real condition of the phenomenon objectively-comprehensively by conducting an in-depth analysis. The location of this research was conducted in Tumbang Tariak Village, Kurun District, and Gunung Mas Regency. The informants in this study were 1) village head and village secretary tumbang tariak, 2) head of BPD, 3) head of sub-district, 4) head of government, head of PMD, and head of ekobang of kurun sub-district, and 5) traditional figures, community leaders, leaders youth and from representatives of women from the village tumbang tariak. The instrument in this study was the researcher himself using data collection tools in the form of a camera, voice recorder, and video. The data sources in this study are generally primary data and secondary data. Primary data is built from data from the results of field studies, namely from predetermined informants, while secondary data is obtained from documents or archives obtained directly (given) from the research location. Data collection techniques used in this study were interviews, observation, and documentation. According to Sugiyono [5], the interview is a technique of collecting data through a meeting of two people to exchange information and ideas through question and answer so that meanings can be constructed in certain topics. Observation is the collection of data through direct observation in the field carefully. Through observation, researchers will be able to obtain clear and concrete images and data on the implementation of bottom-up planning for village development through village development planning deliberations in Tumbang Tariak Village, Kurun District, Gunung Mas Regency. According to Sugiyono [5], data collection techniques through documentation are records of past events. The documentation in this research is in the form of data and legal documents related to or related to the implementation of bottom-up planning for village development as well as other references relevant to the problem under study. The data analysis technique used in this study was data reduction, data presentation, and data conclusion.

\section{RESEARCH RESULTS AND DISCUSSION}

The implementation of bottom-up planning for village development through village development planning meetings in Tumbang Tariak Village can be measured from 3 (three) indicators, namely productivity, efficiency, and satisfaction with planning output.

\section{Productivity}

The productivity in Village Development Planning through the Village Musrebang is seen from the quantity and continuity of the implementation of 
Christira Elyswandi et al., Sch Int J Law Crime Justice, Feb, 2021; 4(2): 105-109

Musrenbangdes activities. In terms of quantity, the implementation of Musrenbangdes is carried out at least 2 (two) times a year or 3 (three) times when the village head starts the implementation of his duties and positions (since the inauguration). The continuity of the Musrenbangdes productivity is seen from the routine implementation every year in accordance with the drafting cycle stipulated in the legislation.

The results showed that the Musrenbangdes activities in Tumbang Tariak village, Kurun subdistrict were carried out in the framework of compiling the village medium-term development plan (RPJM des) which was carried out early when the village head carried out or initiated his duties. Village deliberation activities are also carried out every year in the framework of preparing a village development work plan (RKP Des) and a village income and expenditure budget plan (APB Des) as stated by the head of BPD Desa Tumbang Tariak, Mrs. Diana in an interview on 27 June 2020. This shows that Tumbang Tariak Village can continuously carry out village development planning activities in the musrenbangdes according to the predetermined planning cycle. The continuity of the implementation of village development planning in the village of Tumbang Tariak has been implemented properly and can carry out the process of implementing the bottom up planning of village development through musrenbangdes according to the time schedule set. This condition occurs because the stakeholders at the village level are able to coordinate, communicate, and synergize the potential of all elements. In addition, Tumbang Tariak Village has also implemented a village development planning system and village government work plans according to the established mechanisms and procedures. As conveyed by the resource person in the interview on 27 June 2020, the village RKP was prepared by the village government through a drafting team based on a village head decree and according to information from the district regional government regarding the village indicative ceiling and activity plans of the government, provincial government and local governments Districts. The village RKP began to be compiled by the village government in July of the current year and was determined no later than the end of September of the current year to become the basis for determining the village APB. The compilation of the village RKP is carried out by involving all components of the community. The results of the Musrenbangdes agreement for the preparation of the village RKP are written in an official report. The village head revised the village RKP design document based on the agreement made by the village development planning deliberations. Based on the explanation above, it can be said that the village of Tumbang Tariak has been able to carry out the bottom of planning for village development through the Musrenbang Des continuously and is able to involve various stakeholders so as to get maximum support and have a good impact on the community.

\section{Efficiency}

The development planning implementation mechanism that involves stakeholder community components starting from the RT / RW level and the discussion at the village level greatly creates work efficiency in terms of time, energy, costs, and results as conveyed by the secretary of the Village of Tumbang Tariak Rodiansyah in an interview at June 25, 2020. The results of interviews with several community members stated that most of the plans prepared by the village had met the aspirations and expectations of the community. Most of the village infrastructure has been successfully built, such as village roads, bridges, and village meeting buildings. The village facilities as a whole can be enjoyed and felt by all communities as expressed by the community leader of the village of Tumbang Tariak Darius I Tambun in an interview on June 25, 2020. The village government of Tumbang Tariak, Kurun sub-district stated that it has no difficulties in realizing proposals and community work programs. Villages, because of the relatively large budget and political support through aspiration funds from members of the Regency DPRD and the allocation of village funds (ADD). However, it cannot be denied that not all aspirations and desires of the community or community groups can be fully accommodated due to limited funds. Based on the description above, it can be stated that the implementation of development planning activities through musrenbangdes can select and sort out village priority proposals and parties that submit various proposals are well-coordinated, likewise, the role of community participation has increased significantly compared to the period before the village fund program 1 billion and one villages and the enactment of village laws.

\section{Satisfaction}

The implementation of development through the Musrenbangdes can also be measured from the results or outputs of the plans made. When planning and discussion of development plans have been well defined according to program procedures and priority scales and absorb the aspirations of the village community, community satisfaction will be felt through how the community can utilize and enjoy these development policies to sustain their lives and welfare. As stated by Rodiansyah as the village secretary of Tumbang Tariak, the priority of using village finances is used for various activities that support the implementation of village governance; development and utilization and maintenance of village infrastructure and environment; development, utilization and maintenance of health facilities and infrastructure; development, utilization, and maintenance of educational and cultural facilities and infrastructure; development of productive economic 
Christira Elyswandi et al., Sch Int J Law Crime Justice, Feb, 2021; 4(2): 105-109

enterprises as well as development, utilization and maintenance of economic facilities and infrastructure; environmental preservation; the field of community development; and community empowerment. The priority for the use of village funds is based on the principles of prioritizing justice, namely the rights and interests of all village residents without discrimination. Priority needs are prioritizing village interests that are more urgent, more needed, and are directly related to the interests of the majority of village communities. Almost all of the proposals in the village of Tumbang Tariak, Kurun Subdistrict, determine the priority of village development policies in efforts to improve the quality of life of the village community. Based on the results of interviews, the community is relatively able to accept and have a positive view of the village development work programs that have been determined and are quite satisfied with the implementation of development policies as stated by Martinus, a resident of Tumbang Tariak village in an interview on 20 June 2020 .

The work effectiveness of an organization is influenced by many factors. Both factors that support and hinder or factors that are internal and external to the organization. Measuring the existence of internal and external factors can be seen from the coordination capacity, human resources, and infrastructure. Coordination is a very important component in creating the effect of the implementation of musrenbangdes activities. The implementation of the Musrenbangdes cannot run smoothly, and with quality without good coordination of all components involved in its implementation. The coordination carried out by the village government and the BPD in the implementation of village development planning and the implementation of village development planning deliberations since the enactment of the law on villages (Law No. 6 of 2014) and the 1 billion 1 village programs per village has been relatively better than with the previous time. Good coordination is a supporting factor for the implementation of village musrenbang activities. The village government of Tumbang Tariak, which can carry out coordination activities vertically and horizontally well, can carry out village development planning activities in a shorter time than the village government that does not carry out coordination properly [6].

The success of implementing village deliberation activities for Musrenbangdes activities as measured by the effectiveness of the implementation both in terms of productivity, efficiency, and satisfaction with the results (output) are largely determined by the capacity of village human resources. The ability to coordinate, communicate, and implement effectiveness can only be realized with reliable human resources in implementation. The reliability of human resources is shown by the managerial ability to implement Musrenbangdes activities carried out by formal village leaders, namely the village head and its staff, BPD and its staff, and other village institutions and community components involved in activities and elements of government at the sub-district and district levels. Based on the data obtained, the human resources of the village of Tumbang Tariak are already good with a fairly good educational background and sufficient experience in their fields.

Musrenbangdes activities will only be successful and effective if they are supported by the availability of adequate village facilities and infrastructure. Even though the existence of infrastructure is only a supporting part of the existence of human resources, its existence is sufficient to determine the success of the implementation of objectives. The village of Tumbang Tariak has repaired roads, bridges and almost all access roads in the village area have been well built, as well as village office facilities, village meeting building buildings, sanitation, lighting, clean village water. The village of Tumbang Tariak has also built a village office, a village hall, sanitation facilities, toilets, village Posyandu buildings, and village clean water. So it can be said that the village of Tumbang Tariak already has facilities and infrastructure that can support the existence of human resources in the village of Tumbang Tariak.

\section{CONCLUSSION}

Based on the descriptions in the previous chapters, it can be concluded that the implementation of bottom-up planning village development planning through musrenbangdes in determining and validating village development plans, both the village mediumterm development plan (RPJM desa) and the village government work plan (RKP Desa) has been running effectively seen from the aspects of productivity, efficiency aspects, and satisfaction aspects.

The supporting and inhibiting factors for the implementation of bottom-up planning for village development through musrenbangdes include coordination, human resources, and infrastructure. Overall, Tumbang Tariak village has been able to carry out good coordination with all components including the sub-district government, village administration, BPD, community leaders, and others. Tumbang Tariak Village also has good human resources who have knowledge, skills, and experience and are supported by seriousness and loyalty to the duties and responsibilities handed over to it. Likewise, the facilities and infrastructure in the village of Tumbang Tariak are relatively adequate, such as the availability of village offices, meeting halls, and mobile equipment.

\section{REFERENCES}

1. Fahri, L. N. (2017). Pengaruh Pelaksanaan Kebijakan Dana Desa terhadap Manajemen Keuangan Desa dalam Meningkatkan Efektivitas 
Christira Elyswandi et al., Sch Int J Law Crime Justice, Feb, 2021; 4(2): 105-109

Program Pembangunan Desa. Jurnal Publik, 11(1). 75-88.

2. PKP2A LAN Samarinda. (2010). Efektivitas Perencanaan Pembangunan Daerah Kalimantan. Jurnal Borneo Administrator, 6(1).

3. Adisasmita, R. (2006). Membangun Desa Partisipatif. Yogyakarta: Graha Ilmu.
4. Handayaningrat, S. (1994). Pengantar Ilmu Adminstrasi dan Manajemen. Bandung: CV. Haji Masagung

5. Sugiyono. (2008). Memahami Penelitian Kualitatif. Bandung: Alfabeta.

6. Undang-Undang No. 6 Tahun 2014 tentang Desa. 